\title{
Decolonising the higher education curriculum: An analysis of African intellectual readiness to break the chains of a colonial caged mentality
}

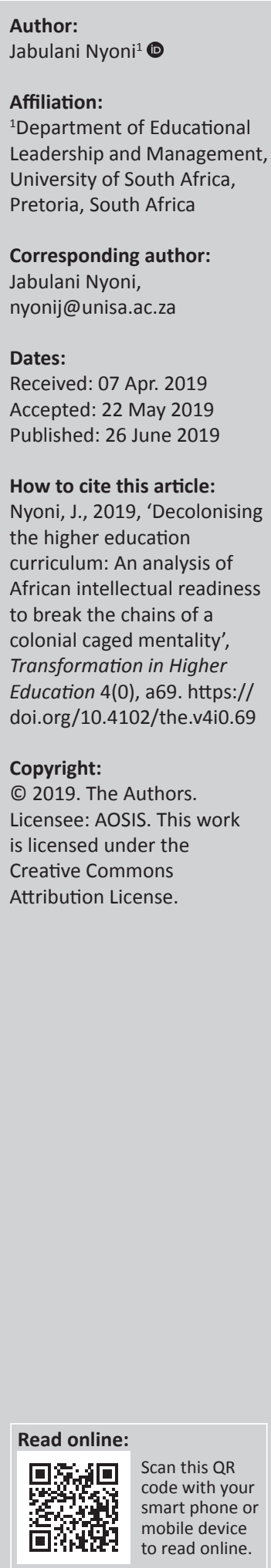

Background: Forging 'new' decolonial education curriculum policy reform with ill-conceived intents may lead to both socio-political and economic pathologies and failure.

Aim: The aim of the social sciences meta synthesis done was to consolidate gathered evidence from published scientific articles on decolonial curriculum reform policies. It was critical during the process of synthesising to acknowledge the fact that Africans continue to experience multifaceted socio-political and economic shifts of being as influenced by a variety of global ideologies. Concerted decolonial efforts should be made to manage these matrices of material social constructs such that the contamination and decapitation of true African educational curricula, identities, cultures, values, ethos and principles are curtailed.

Setting: The critical exploration of meta-data underpinned by a critical-dialectical perspective attempted to dig beneath the impact of coloniality of power on the conscious mind of an African intellectual. The critical social research analyses how the African colonised mind can effectively decolonise African university curriculum given their colonially captured mind.

Method: An extensive search, guided by selected key words, yielded about 35 articles on decolonisation but were trimmed down to 15 as determined by my main focus thus: decolonial curriculum reform in post-colonial nation states.

Results: Findings indicate that African scholars, political pundits and researchers tend to rely on the mentally embedded notion of caged colonial mentality (CCM) in advocating for decolonial curriculum reform, with little regard for the multifaceted seismic shifts that impact on the socio-politico-education life of post-colonial African existential Beings.

Conclusion: I strongly advocate for the dismantling of systemic CCM and embrace those seismic shifts that incorporate contemporary decolonial projects when crafting the architecture for decolonial curriculum designs that build on appropriate knowledge, competences, skills, values, beliefs and practices from around the globe to buttress multiplicities of identities, while nevertheless retaining Africa's interests at the centre.

Keywords: Multifaceted Seismic Shift Matrix; architecture for decolonial curriculum designs; multicultural hybridity; decoloniality of power; caged colonial mentality; CCM; Afro-Communalitarian Theory.

\section{Introduction}

An African society, in my view, should be composed of Beings who are accorded the rights to values such as freedom, social justice, equality, human dignity and choice of education curricular paradigms. African collective communal projects have in their design invariably been conceptualised for the survival and sustenance of their participants, irrespective of status, class and gender. However, one of colonial rulers' policy was the desire to control educational projects. They found it necessary to impose curriculum changes as experienced in the 1960s. From about the 1980s, migration patterns from other parts of the world, Africa included, into some European countries and North America compounded by imposition of segregatory laws by colonial powers, invoked discourses of cultural diversity and inclusion in colonial states. Discourses among others centred around issues of curriculum decolonialism and how Africa, Caribbean Islands, Asia, black Americans and other first nation peoples would be impacted by envisaged changes, including the West itself. The journey of becoming has gained traction, intensified by the disruption demand for decolonised forms of education in African universities. Critical curriculum decolonisation is used among African indigenous intellectuals around the 
globe, where a variety of models of decolonial education have emerged. Decolonial thinking about education is rooted in the violent occlusion of 'ways of knowing' and being among indigenous civilisations in Africa within the imposition of a new world order post Imperial order. The conquest of Africa meant the demolition of indigenous, political, education and economic systems. Universities' generation of post-colonial knowledge and epistemologies need to be agile and accommodate waves or demands of curriculum transformation and change to accommodate Afrocentric developmental projects.

Curriculum projects are neither final nor static but are instead a journey. Decolonial education curriculum is an expression of the changing geopolitics of knowledge where the modern epistemological framework for knowing and understanding the world is no longer interpreted as universal and unbound by geohistorical and bio-graphical contexts (Mignolo 2011). Thus, the African critical thought on decolonial education curriculum reform should endeavour to address questions of genuine decoloniality and transformation, such as how radical education curriculum reform at the academic, cultural and psychological levels can contribute to the processes of deimperialisation in institutions of higher learning. The challenge for professoriates and lecturers is to learn how to teach or facilitate beyond the distorted cultural and/or historical imaginary and impoverished subjectivity of the modern horizon of thought where everything is hierarchically ranked according to Eurocentric concepts, standards and assumptions. The African content should be one of the multiples of global centres of epistemological origins and underpinnings of social reconstruction of reality and dissemination.

\section{Overdeterminism of decolonial analysis discourses}

In brief, decolonisation is the disruptive endeavour to end colonialism; it is the liberation and de-caging of the colonised, caged mind by shifting the focus away from Western perspectives as the centre for development. Deconstructive decolonisation discourse envisages acknowledging Africa as one of the regional centres of epistemology generation, with its own developmental intricacies, and as such worthy of being viewed as an equal global partner. Africa must be allowed to reassert its own native knowledge and socio-political and economic systems. This requires the dismantling of the colonial government and its entire social fabric, upon which control and exploitation are based. For decolonisation to have a profound effect, the process of destroying the colonial pathogens that have kept the black mind chained must be instituted. Fanon (2008 [1952]) writes: 'the juxtaposition of the black and white "races" has resulted in a massive psycho-existential complex' (2008 [1952]:xvi). His book, Black skin, white masks, 'is meant to liberate the black man from the arsenal of complexes that germinated in the colonial situation' (Fanon 2008 [1952]:14) - in other words, Fanon underscores the need for the black person to overcome the psychological or mental effects of colonialism. Another interpretation is that the colonial context affected the way in which people learnt to think about themselves and others, and that this way of thinking is not necessarily changed through political change alone. Afrocommunalitarian theory seeks to explain the understanding of the native person in relation to the Afro-humanisation of pedagogy and show how this application of a concept rooted in Africa to the issue of pedagogy can provide new, deconstructed insights into and fresh perspectives on the issue (Heleta 2016). It seeks to proudly urge Africans to use their culture, language and knowledge in constructing Afrocentric curricula and thus reasserting their own organic epistemological centre.

\section{The dilemma relating to African education developmental agendas post-independence}

The focus of this article is on African education curricula, which remain largely Eurocentric and continue to reinforce white and Western dominance and privilege and at the same time are laced with stereotypes, prejudices and patronising views about Africa and its people. Africa must completely rethink, deconstruct, reframe, reconstruct the Eurocentric and colonial curricula as well as teaching methods at universities.

Decolonisation of higher education is 'about justice that addresses the epistemic violence of colonial knowledge and colonial thought' (Pillay 2015). Decolonisation is a project that many have rightly interpreted as an act of defiance against all Eurocentrism. Derrida (1982) states that, 'this act of "defiance" is deconstruction itself'. It therefore matters little if one is labelled academically dissonant and dissident, if Africa is locating or claiming its own indigenous or native centre for knowledge production and dissemination.

There is an urgent need to radically decolonise curriculum change and research projects. The adopted radical approach should be aimed at managing racial undertones, promoting gender equality and other forms of 'isms' that breed discrimination, cultivating the need to achieve qualitative throughput rates at African universities in line with appropriate and fit-for-purpose Afrocentric developmental trajectories.

\section{Closing the gap between academic achievement and the people}

African epistemology and underlying philosophies should underpin Afrocentric developmental endeavours as the focus as well as project Africa as one of the centres of knowledge generation. What is needed in this complex decolonialisation endeavour is the analysis of African intellectual voices through texts, and their conceptualisation of the 
decolonisation of Afro-centred knowledge generation and dissemination despite the embeddedness of conflictual caged colonial mentality (CCM).

The article analyses challenges faced by a caged African colonial mentality critical intellectual in effectively deimperialising embedded education legacies, global values and epistemological superiority.

\section{Bracketing the focus and scope of my article}

I began my research by carrying out a meta synthesis of the literature on decolonial curriculum reform in higher education (HE). This revealed that although some research relating to decolonial education has been conducted, no effort has been made to investigate the decolonisation of the CCM of the scholar who is expected to spearhead African organic decolonial intellectualism. Texts relating to the focus of my article included the works of scholars such as Grosfoguel (2007); Mignolo (2007); Mazrui (1986); NdlovuGatsheni (2013); Mashau and Mangoedi (2015); Dei (2018); Ngugi wa Thiong'o (2009); Fanon (2008 [1952]); Derrida (1982); Maldonado-Torres (2015); Quijano (2007); Bhabha (1994); Mbembe (2016); Du Bois (1999) and Spivak (1990). However, I acknowledge the fact that some of the listed authors who are sampled write about decolonisation in other settings or contexts, not necessarily about the African continent.

\section{Rejigging the caged colonial mentality and the decolonial curriculum}

It is possible to argue that decolonial conversations violate informal rules by going against what are construed as Western formal 'ways of doing things'. The West has, for centuries, developed a body of knowledge that the rest of the universities (including those from former colonies) must copy in compliance with Western standards. One of the misconceptions held is that reading decolonial literature will not be adequate to make critical scholars trapped within CCM frame of mind become experts in the architecture of decolonial curricular projects at universities. For example, South African universities continue to dither about or tinker with decolonial curricular reform because lead professoriates lack decolonial ontological and epistemological requisite competences for the project to succeed. Professoriates and students should learn to recognise the power relations intertwined with African contextual epistemology, or how knowledge disciplines are embedded within the body and geopolitics of the modern world order. However, decolonial discourses and efforts to decolonise curriculum began after independence particularly in independent countries such as Ghana, Kenya and Uganda, to name but a few. Despite the many advancements in the study of psychoanalytic theory since Sigmund Freud introduced his theory in the early 1900s, the basic tenets of Freudian thought continue to exert a significant influence on thinking about the human mind. Experiences by nature are acquisitions of skills, competences and knowledges gained through practices over a period. Empirical knowledge refers to knowledge gained through practical experience.

To know how (commonly known as procedural knowledge rather as propositional knowledge) is the notion of experience. Human beings' experiences are products of their environments, and the knowledge gained is embedded in their consciousness. Content of consciousness is a part of beliefs, emotions and largely thoughts gained by nonconscious process that lie in the human brain. Indeed, from this point of view, our minds are not merely a flow of immediate experience, but a huge repository of hidden depths: beliefs, attitudes, motives, suspicions, hopes, fears and much more acquired over time.

For centuries an African mind has been fed Eurocentric imperial education experiences that denigrated and subjugated African cultures, civilisation, language, rituals and traditions through the policy of containment and control. To break the debilitating cycle of CCM, African intellectuals should not continue referencing Foucault, Rousseau, Hegel, Heidegger, Newton, Galileo, Darwin, Gramsci, Chomsky, Socrates, Aristotle, Marx, and other authors who may not relate culturally to African discourses but invariably counterbalance their views with authors who come from Africa to advance African epistemologies. The richness and success of the African 'Beings' is not dependent on what Western critical seminal authors make of it but is dependent on what the critical African scholars offer as effective leadership in decolonial projects. For example, some African critical scholars conceptualise civilisation, modernisation and exposure as defined in terms of a total disconnect from African culture but the West. The material process of disruptive deconstruction, of deimperialisation and the destruction of Western-inspired educational pathogens includes taking painful steps towards the rejigging and reorienting of an African CCM.

\section{Historical language production as viewed through a Western lens}

History became the product of the West in its actions upon others. At the same time, it displaced those actions through the idea that modernity was endogenous to the West, and therefore removed the very notion of the 'other' in history. In so doing, it also naturalised and justified the West's material domination of the 'other', and in this way suggested complicity between Orientalism as scholarly discourse and as imperial institution. As Said (1995 [1978]) suggests, it was no accident, then, that the movements for decolonisation from the early twentieth century onwards were to provoke a fundamental crisis within Orientalist thought: a crisis that fractures the complacent rendering of the 'other' as passive and docile and that challenges the assumptive conceptual framework underpinning such depictions (Said 1995 [1978]). 
Bhabha (1994) contends that there is no singular event of modernity and there are no moderns (that is, those who have lived through modernity); rather, modernity 'is about the historical construction of a specific position of historical enunciation and address', and much can be learnt through examining the spatial contours given by theorists to the time of modernity. The insistent location of modernity in the French and Industrial revolutions, for example, reveals the power of centralisation of knowledge generation and custodianship.

\section{The locale of an African voice in 'development appropriateness' discourse}

As Africans continue to experience multifaceted sociopolitical and economic shifts of being as influenced by a variety of global ideologies, their voices continue to regurgitate Western epistemologies consistently and impactful decolonisation efforts remain negligible and mentally captured. Concerted decolonial efforts should therefore be made to manage shifts in these matrices of material social constructs such that contamination and decapitation of true African education curricula, identities, cultures, values, ethos and principles are prevented. African voices should be allowed to correct the toxic, Westerninspired nuances and narratives underpinning Westerninduced education curricula.

Thus, knowledge production is crucial to developmental aspects of the Third World such as peaceful coexistence, selfdetermination, economic prosperity and many other 'concrete manifestations of freedom' (Gordon 2011:101) that can serve as markers of the emergence of a truly 'decolonised world'.

The question that emerges from this understanding of decolonialism, rather than colonialism, is: Does the manner in which historical knowledge production takes place within what is today dubbed post-colonial Africa reflect and accommodate the worldviews and aspirations of all who live there, or does it present only Eurocentric perspectives on African history? This question is critical because during colonial encounters between Africans and Imperialists, the voice of the European settler, and particularly that of the literate missionary, constituted the major source of the historical deconstruction of African history (NdlovuGatsheni 2011:93). Disruptive efforts are critical in achieving decolonial projects and socio-political agendas, yet the pushback emanating from Western commentators and empathisers is huge. The power balance is heavily skewed against the genuine call for decolonial thrusts.

\section{Setting free those trapped within the African caged colonial mentality}

In his speech to the 1960 Pan-African Congress, Patrice Lumumba, the first indigenous leader of the Republic of the Congo, called for mental decolonisation, urging Africans to 'rediscover our most intimate selves and rid ourselves of mental attitudes and complexes and habits that colonization ... trapped us in for centuries' (Nyoni 2013:86). One might surmise that post-colonial African state craft has consistently been framed within CCM. A cage is an enclosed structure in which birds or other animals are confined or restricted behind bars, wire or netting. In this article, CCM refers to mental self-confinement by African intellectuals who restrict their technocratic and intellectual craft competences, craft literacies and ideological thought within narrow Western traditional prescripts. Caged colonial mentality restricts African mental power from functioning critically outside the box in accommodating African indigenised contexts. For example, the partitioning of Africa was an illegal act of occupation, carving up, and subsequent colonisation of African territories by Western powers during the time of partitioning, between 1881 and 1914. Africans continue to mimic imperialist politics in both character and architecture by design and application to date. The so-called African democratic structures embrace imperialist choreographies and architectures in social structures such as education, health, police, defence and home affairs, following on from the colonial past. On the other hand, CCM also affects those intellectuals, both black and white, who resist any attempt to confront Westerninspired skewed ideologies and beliefs.

To them, Western values and perspectives represent best practices in African-developmental agendas. Both sets of protagonists (both black and white intellectuals) remain captured in their Western-valued niceties and propensities, as neither knows how a truly emancipated independent African intellectual mind should think in order to craft appropriate African decolonial epistemological projects.

The most frightening irony in decolonial projects is that intellectual experts with no decolonial craft literacy and competency are expected to drive processes of curricular reform and knowledge generation. Biko (1987) reiterated the need for Africans to tackle the challenge of 'mental slavery'. A CCM has produced a colonised approach to development and instruction. In discussing Africa's maladjusted development trajectory, Mazrui (1986) cited the example of Japan in order to demonstrate how, by contrast, African elites failed to choreograph their Western education with their African values in both their own intellectual development and the continent's progress. African intellectuals need to think first from the point of view of an African value-based system with the enabling aspects of colonial legacies and global values, and then intellectually link these to the wider world of scholarship and science.

\section{Decolonising the African colonial caged mind \\ Multifaceted seismic matrix of shifts in African mind-set capturing and caging}

Caged colonial mentality refers to mental self-confinement by African political elites and scholars who restrict their 
technocratic competences, craft literacy and ideological thought within narrow Western prescripts. Failing to acknowledge that 'freedom has dawned in Africa', African elites continue to restrict their mental power to operate critically outside the box to accommodate African contexts. The unfrozen mind (seismic shift) can design decolonial curricular constructs that build on the best knowledges, competences, skills, values, beliefs and practices from around the globe to buttress their causal multiplicities of identities (see Figure 1).

In post-colonial Africa, the caged colonial mentality continues to influence structures of leadership and curricular reform. The coloniser's mind (colonial mind-set) sees nothing wrong with current African university curriculum. The colonisee's (African colonised mind-set) feels curriculum has to transform (see Figure 2). The status quo remains (conflictual divergence). The conflictual divergence has an impact on decolonial curriculum at African universities.

Social overdeterminism (SO) is a socio process that was evidently displayed by the South African \#DecolonialEducation student protests in post-apartheid South Africa. In context, social SO denotes a single observed effect; \#DecolonialEducation for example is determined by multiple causes, thus, any one of which would be adequate to determine the effect. It will mean therefore that there are more causes in existence than necessary to cause the effect (Freud 2010). Freud (2010) was among the first seminal theorists who conjured up the logic of overdeterminism. The critical thinking behind the theory was to replace the idea that social structures that were always in a state of flux were capable of being altered progressively in many ways.

The following can be some of the social causes of discontentment that we must also acknowledge:

- The fatalities of Western colonialism projects when embarking on our own decolonial education curricular reform.
- That Africa is no longer composed of insular monocultural societies, but in response to shifts over time has become hybrid in its configurations of being and composition.

- That Africa still battles with social homogenisation, ethnic foundation and cultural delimitation - the foundations of xenophobic outbursts.

- That the functions of Africa's post-colonial states remain steadfastly caged within debilitating political and economic limitations that inhibit genuine reforms restrictive bureaucratic borderisation and ring fencing, colonial education curricula and state power debacles, and many more.

- That the Africa of today is characterised by multiculturality, interculturality and intraculturality.

\section{Embedding matrices of shifts in decolonial projects}

Disruptions that represent a matrix of shifts akin to those that have shaped African socio-economic and geopolitics at key moments over the past 1000 years need to be accommodated in contemporary decolonial curricular reforms. It is the narrative of African social disruption of nations, disruption of economic projects, and disruption of African body politics, of social cohesion projects and of education from cradle to grave. The West's disruption of African constructs caused African Beings to undergo a traumatic matrix of shifts in compliance with the imperial social order of existence. These included the

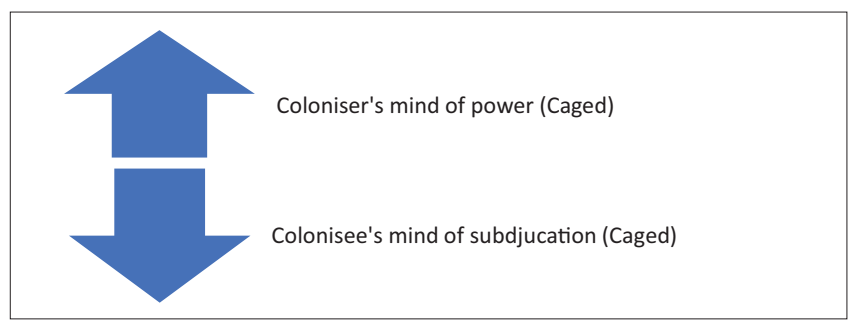

Source: Nyoni, J., 2013, 'Decolonial multicultural education in post-apartheid South Africa', International Journal for Innovation Education and Research 1(3), 83-92

FIGURE 2: Two opposing ideological standpoints (minds) that diverge from a central point.

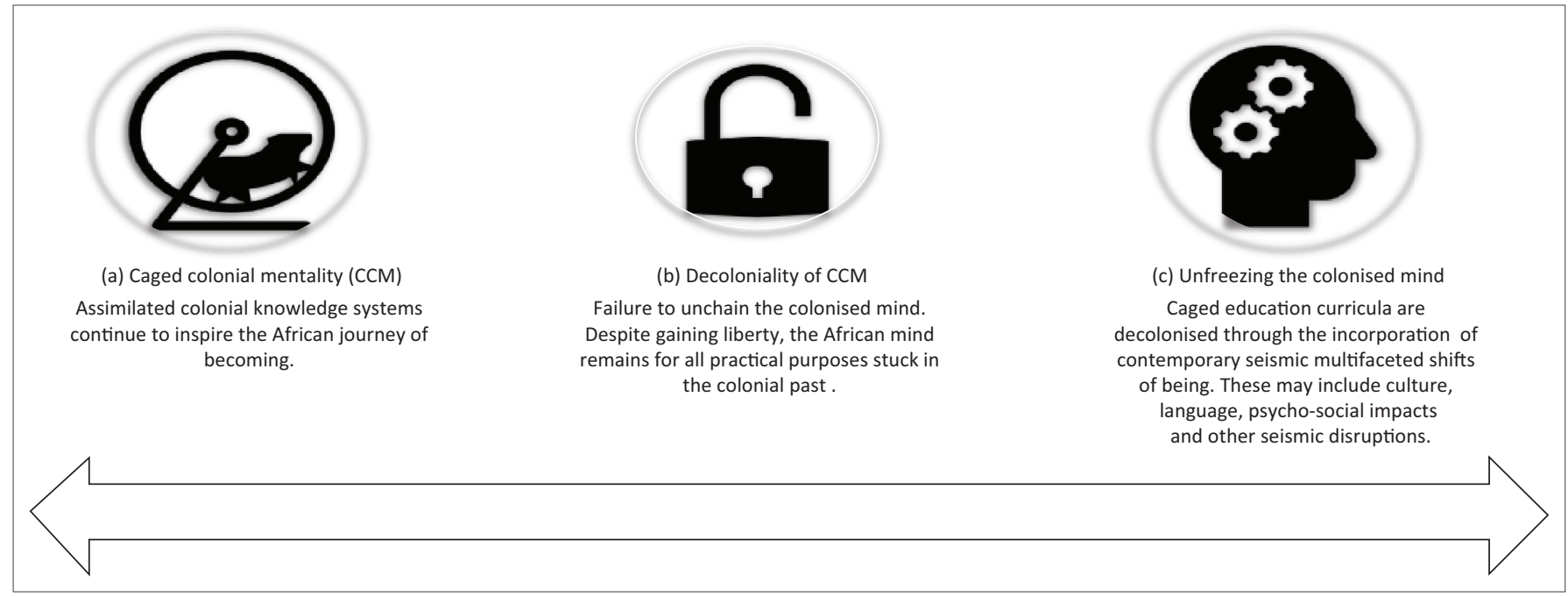

Source: Nyoni, J., 2013, 'Decolonial multicultural education in post-apartheid South Africa', International Journal for Innovation Education and Research 1(3), 83-92 FIGURE 1: Multifaceted seismic matrix of shifts in African mind-set capturing and caging. 
dilution or disruption of the cultural ethos (or both) owing to forced displacements, disruption of political systems, forced social disintegration at places of work (the migrant labour system), disruption of communitarian settlements and the subsequent creation of new patterns of settlements, disruption of language of communication and the partitioning of Africa through the introduction of new borders that separated families. The colonial projects of capturing and caging the African mind began during the period of conquest and dispossession and the West's quest to monopolise the economic resources of the known African continent. The embeddedness of the Western policy of capture and control emphasised the view that the West was or is the regional centre for knowledge in the global contest and conquest. In contrast, decolonial projects must accommodate multiplicities of knowledge systems, provided Africa remains one of the regional centres in the global village. Never should there be only one centre for knowledge generation.

\section{Decolonising African curricula by de-caging the mind}

Although universities in Africa enjoy academic freedom, their curricula continue to promote Western thought and ideas that maintain the hegemonic status quo as regards knowledge, teaching, learning and research. Governance systems, academic agendas and curriculum design reflect Western influences. The Eurocentric body of knowledge continues to encourage students to enter the marketplace, but they are not adequately prepared to make fundamental changes to the status quo in society and the economy.

Quintessentially, decolonisation should aim to engage with the diverse experiences and perspectives present in every culture and part of the world instead of blindly following Western 'universalism' and the notion that Europe and the West are the centre of all knowledge. An African intellectual should promote Afrocentric developmental agendas and not look to the West to proffer solutions for Africa. A hybridity of ideas should be mobilised to contribute towards the African centre of development and advancement.

\section{Challenges of post-colonial states}

Early critical thought on decolonisation attempts began in the period between 1940s and 1950s in the United States by scholars such as Martin Delany, Alexander Crummel and many others. Such decolonial ideas influenced Pan Africanist member of the name of Kwame Nkrumah of Ghana. The African critical thought at that time was to fight influences of CCM with the aim of shifting political and educational paradigms away from imperial capture and control. Kwame Nkrumah and his Pan Africanist friends believed that decolonisation should aim at extinguishing all colonial rule in African and other colonised peoples of the world and advocated for Africans to unite politically and economically.

Pan Africanists' ideas resonated with other African leaders who were fighting for liberty, freedom and independence wherein in 1963 the Organisation for African Unity (OAU), which is known as African Union (AU) currently, was established in Addis Ababa, Ethiopia. The struggle of decolonisation saw the establishment of other ancillary political formations such as Economic Community of West African States (ECOWAS), Southern African Development Community (SADC), Frontline states, Common Market for Eastern and Southern Africa (COMESA), to name but a few.

However, as CCM will dictate, African post-colonial states experienced challenges in forging economic opportunities and political stability. Infrastructural development projects stagnated, state apparatus and its technocrats were inexperienced, and social challenges ballooned to a state of decay. Moreover, the political system that African leaders inherited was captured to benefit the evolving ruling classes, with little regard for the needs of the people and economic development.

There were few real efforts beyond the political speeches of Kwame Nkrumah - first president of Ghana, who held office from 1957 to 1966 - and the words of the founding charter of the OAU, encouraging members to look beyond the accepted borders towards pan Africanist or even regional confederations, were constrained by a CCM. African political, social and economic progress was dependent upon Westerncontrolled funders such as the World Bank and the International Monetary Fund (IMF).

\section{Lack of utopian African education}

Utopians view teaching experiences not as a means of imparting knowledge, but as a process of 'creating attitudes by shaping desires and developing the needs that are significant in the process of living' (Dewey 1934:139). The Utopian approach entails designing environments to foster interest, allowing children to pursue unique lines of individual development.

The structure of schooling in Utopia follows the way in which learning occurs naturally in social life, that is, as a function of increasing participation in culturally meaningful activity. Dewey had been making this point for 30 years by the time he gave his Utopia speech; in his Pedagogic Creed of 1897 he wrote: 'The most formal and technical education in the world cannot safely depart from' the general process by which individuals appropriate 'the social consciousness of the race'; that is, learning as a feature of participation in social activities (Dewey 1934:133).

The purpose of education (Dewey 1934) was clear: functionalism was the main guiding principle. African society regarded education to an end, not as an end in itself. Education was generally intended for immediate induction into society and preparation for adulthood. African education emphasised social responsibility, job orientation, political participation, and spiritual and moral values. Children learnt by doing, and children and adolescents engaged in participatory ceremonies, rituals, imitation, recitation and demonstration. 


\section{A reimagined, humanised andragogy and pedagogy}

Humanising pedagogy and andragogy will encourage engagement with Western material, if it is with the understanding that Africa, and African students, have a valuable perspective to contribute alongside what is found in the Western canon. Freire (2000:90) posits that:

$[T]$ rue liberators' practices reject humanitarianism and approaches that view someone experiencing oppression as a passive object; instead, they embrace what he called humanization, which focuses on one's own power and agency in the personal and collective struggle for freedom.

Dogmatic approaches to content knowledge and dissemination can play no part, as they stifle the critical thinking needed to indigenise problem-solving skills and competences.

In African settings, different meeting practices are followed with ritual precision and follow protocols. For example, in traditional historical African societies, gatherings were held to make decisions and to discuss issues that affected the community. Almost 17 million people, or a third of the population of South Africa, reside in the former homelands, which the post-apartheid government calls 'communal areas', according to forms of communal tenure. Cousins (2008:129) articulates a similar notion of communal tenure, describing communal tenure as inclusive and 'socially embedded'; 'land tenure was [and is] both "communal" and "individual" and can be viewed as a "system of complementary interests held simultaneously" by different people. In other words, communal tenure systems are based on the idea that individuals and families hold relative rights to the same residential and agricultural land. These relative rights may even overlap. Decolonised communal practices and cooperative efforts are largely influenced by Afrocommunalitarian theoretical underpinnings.

Afro-communalitarian theory (Afro-Communalism) seeks to explain traditional socio-economic and political structures that define the characteristics of communally shared natural resources, knowledge and wisdom, infrastructure and so on. The traditional lekgotla [a meeting called to discuss strategic planning for a village etc.], for example, has been used for centuries for village assemblies and village leaders' meetings. There is also the indaba [an important meeting called by a chief or headman of a village], historically an important conference held by the principal men of a communal area or with representatives of other communities, and the imbizo [a gathering], a forum for policy discussion. As a result of pressure from within Kalkfontein, over time women also became part of the dikgotla [several meetings held at different places] that make decisions about land, meaning that women's claims on land were also being weighed up in relation to men's and other women's interests (Claassens \& Gilfillan 2008). There are no doubts many more variations on approaches to meetings, based on a wider range of perspectives.
Failure to unchain or de-cage the 'caged' mind will mean that decolonial efforts will do nothing more than offer patently cosmetic changes that remain marooned within Western knowledges and practices. Reading through the literature, I noticed with some distress that scholars tend to conflate concepts such as multiculturalism, diversity and equity with decolonialism (Day 2004; Nyoni 2013). Cultural diversity is a strategy for 'embracing, or accommodating or engaging differences' (Naidoo 2015:3). Multiculturalism is based on the principle and concept of nation state which emphasise regional, linguistic and cultural union. It has been accepted in response to the management of nation state by including the cultural diversity within in the political community (Journet 2009). Decolonisation is disruptive process of exposing and dismantling the obvious and hidden aspects of those institutions, linguistic and cultural forces that had maintained the imperialist power and that remain even after attainment of independence.

\section{Critical rationale for decolonial literacy and competency acquisition}

The term 'decolonial literacy' in this article refers to an innovative approach that provides a framework for combining character development with decolonial education in order to raise a generation that is mentored to become conversant with decolonial imperatives that underpin developmental agendas for Africa. The term 'decolonial competency' embraces a range of competence skills that a decolonial expert can apply in analysing, interpreting and applying expert knowledge when tackling decolonial projects.

While decolonial experts attain the necessary understanding of decolonial literacy and competence during workshops, conferences and other forums, they are mentored to work as teams within their family and community structure to implement this knowledge in their daily decolonial lives as well as the lives of others around them. The following are some of the concepts that are embedded within decolonial literacy and competence.

\section{Understanding inclusion}

There is a huge fallacy by other scholars that tend to define 'inclusion' as an academic effort by an educator to cater for differently gifted learners. Nothing can be further from the truth! In this article, inclusion refers to catering for different groups of ordinary people individuals within an organised society organisation, such as university, where a variety of culturally diverse people, religions, races, ethnic, languages, colours or creeds endowed with diverse knowledge, skills and competences are treated equally. The plurality of differences among peoples of diverse cultures makes it more challenges for institutions of higher learning in Africa to decolonise practices as their intents are hampered by CCM to a certain extent. Despite the challenges one believes that benefits of decolonial inclusion are immense. University students, for example, feel accommodated in all academic 
spheres, respected and are part of decolonial projects. But for all this to materialise, there should be a mind-set shift on the part of institutions of higher learning and culture of practices thereof. Curriculum reform must speak to students' cultural diversity, experiences and Africa's developmental agendas. There should be a balancing act exercise regarding national origin, age, race and ethnicity, religion and/or belief, gender, marital status and socio-economic status of students.

Inclusion is a sense of belonging. Inclusive cultures make people feel respected and valued for who they are as an individual or group. People feel a level of supportive energy and commitment from others that enables them to do their best at work. Inclusion often means a shift in an organisation's mind-set and culture that has visible effects, such as participation in meetings, how offices are physically organised or access to facilities or information.

\section{The concept of cultural diversity}

The concept of cultural diversity embraces tolerance, acceptance and respect. Decolonial education policy designs should address matters of cultural diversity with a prime focus on the ethnic multiculturalism, religious belief systems, race, gender, sexual orientation, socio-politico and economic, differently gifted people and other ideologies. Decolonial efforts must help build more intercultural and inclusive societies irrespective of geo-political position in the globe. Quite frankly it must make use of raw human and material resources to improve organic teaching and learning experiences that contribute to more complete human development and to transform cultural diversity into realms of understanding, pluralism and social cohesion.

The social justice model evolved next and extended the idea that individuals outside the dominant group should be given opportunities within the workplace, not only because it was instituted as a law, but because it was the right thing to do. Kevin Sullivan, a former vice-president of Apple Inc., said that 'diversity initiatives must be sold as business, not social work'. This model still revolved around the idea of tokenism, but it also brought in the notion of hiring based on a 'good fit' (Bala 2013).

According to the deficit model, it is believed that organisations that do not have a strong diversity inclusion culture will invite lower productivity, higher absenteeism and higher staff turnover, which will result in higher costs to the company.

This very general discussion prepares the way for a mention of the cultural hybridity debate. Hybridity, as it is understood in post-colonial theory, is perceived as having the potential to go beyond the sort of modern binaries from which, Beck (2005) suggests, contemporary social imaginaries must find a way out.

According to Pieterse (2001:238), 'Hybridity is to culture what deconstruction is to discourse: transcending binary categories' (Pieterse 2001:238). Yet, as is pointed out in many works discussing cultural hybridity, the term and the vast array of concepts it encapsulates have raised long-running discussions and debates. The term 'hybridity' refers notably to discourses and ideologies of racism (Nyoni 2013). Derived from the Latin, the term was until the 19th century rarely used except in biological or botanical descriptions. However, Young points out that it had also previously been used in the context of race mixture (and especially in relation to human fertility). He further relates the definition found in the OED to other, previously used terms such as 'mixed' or 'intermediate races'. The significant point in Young's account of the increasing use of the terms 'hybrid' and 'hybridity' (and their eventual inscription) in the 19th century is that it 'marks the rise of the belief that there could be such a thing as a human hybrid' (Young 1995:6) - the belief, in other words, that there are objective different human races (or 'species').

One of the major contemporary theorists recently associated with cultural hybridity is Homi Bhabha. In most of his works, Bhabha (1994) considers the interrelations and interdependence between the colonisers and the colonised. Through the colonial experience, the social categories exerted on the colonised (the ideas of superior and inferior human races and cultures, for instance) imprint an imaginary that collides with their own, 'displacing' or 'disjuncting' it. This 'encounter' eventually creates new 'hybrid' expressions (of culture, of belonging), which in turn challenge the beliefs and experience of the colonisers. Bhabha (1994) argues that these colonial - and postcolonial - cultural systems and statements are constructed in a 'liminal space': the 'Third Space of Enunciation' (Bhabha 1994:209). Hybridity, according to Bhabha (1994), opens what he calls 'a third space' within which elements encounter and transform each other (Papastergiadis 2000:170; Young 1995). It is, concurrently, the site of struggle and resistance against imperialist powers (Kraidy 2002:316). With the goal of abolishing the distinctions between centre and periphery, and other forms of binarism, this post-colonial interpretation of cultural change is a significant departure from the linear diffusion model of 'the West to others'.

\section{Decolonising Equity Pedagogy in curriculum change}

Equity pedagogy exists when facilitators use techniques and methods that facilitate the academic achievement of students from diverse racial, ethnic and social class groups. Equity pedagogy consists of a review of selected studies of approaches, theories and interventions designed to help university students who are members of low-status population groups to improve their academic achievement (Delpit 1988; Ogbu 1990; Shade 1989). In education, the term 'equity' refers to the principle of fairness. While it is often used interchangeably with the related principle of equality, equity encompasses a wide variety of educational models, programmes and strategies that may be considered fair, but not necessarily equal. It has been said that 'equity is the process; equality is the outcome', given that equity - what is 
fair and just - may not, in the process of educating students, always reflect strict equality - what is applied, allocated or distributed equally.

Multicultural education prescribes what actions should be performed in order to ensure equitable accessibility and treatment for diverse groups in schools and in society. Some authors equate multicultural education with a 'renewed and refined version of liberal education, education for freedom and celebration of the inherent plurality of the world' (Banks 2001:28). Banks (2001) distinguishes three dimensions of multicultural education definition: multicultural education as an idea, educational reform movement and a changing educational system structure process. The purpose of multicultural education is to equalise educational opportunities for culturally different students. Fundamentally, academic failure of students from certain minority ethnic groups whose university performances continue to stay behind national norms can be linked.

Cultural diversity offers a plethora of possibilities when looked at with a different lens. For Africa's post-colonial education systems, the question of how to decolonise HE curriculum is still relevant today. Some university professoriates find it extremely difficult to address issues of decoloniality owing to profound impact of CCM. The prevailing tendency at these institutions of HE is to simply make insignificant tweaks of the curriculum reforms. There lies the danger of being alienated by the society or being revisited by student protests and failure to contribute towards effective development and economic emancipation. One would argue that titanic shifts are needed in curriculum change in order to make visible dents in decolonial projects.

\section{Recommendation}

In seeking to unmask and challenge colonial logic that underpins homogenising education constructs across disciplines and to affirm the anti-colonial theoretical foundations of epistemic resistance rooted in indigenous spirituality, ways of knowing and being, this contribution offers vital conceptual tools and pedagogica or andragogical possibilities for advancing the global struggle to humanise knowledge production and anti-racist education practice. Afro-communalitarian theory seeks to explain the understanding of the person in relation to the concept of Afrohumanisation of pedagogy and show how this application of a concept rooted in Africa to the issue of pedagogy can provide new, deconstructed insights into and fresh perspectives on the issue. One might therefore recommend that aspiring education curriculum reform practitioners can participate in decolonial studies, colloquia and development programmes to acquire appropriate skills and competences as these relate to decolonial practices and praxis.

\section{Conclusion}

Ill-conceived disruption of 'new' decolonised education curriculum reconstruction and reform by those uniformed about decolonial craft skills and competences may lead to the production of both socio-political pathologies and education failure. It is important to emphasise, however, that African decolonial deconstructionists and curriculum reformers struggle to de-cage their theories, undergirded by CCM, from the comfortable web of colonial educational and political niceties. Concerted decolonial efforts should be made to manage decolonial shifts in the matrices of material social constructs such that the contamination and decapitation of true African education curricula, identities, cultures, values, ethos and principles are curtailed. CCM stems from the fact that African political, educational, economic and social systems are structured based on past colonial technocracies. It is unfortunate but natural that African critical thinkers should alternate between conscious and subconscious minds when faced with the task of decolonising curricula. When merely superficial efforts at curriculum change are made, authentic decolonial efforts fail.

\section{Acknowledgements}

My sincere gratitude to the University of South Africa for having allowed me to contribute towards decolonial discourse as well as Transformation in Higher Education for publishing my article.

\section{Competing interests}

The author declares that no competing interest exists.

\section{Authors' contributions}

I declare that I am the sole author of this research article.

\section{Ethical considerations}

All ethical considerations and processes were complied with in terms of standing legal requirements.

\section{Funding}

Funding for this study was obtained from the University of South Africa.

\section{Data availability statement}

Data sharing is not applicable to this article as no new data were created or analysed in this study.

\section{Disclaimer}

The views and opinions expressed in this article are those of the author and do not necessarily reflect the official policy or position of any affiliated agency of the author.

\section{References}

Bala, I., 2013, 'The psychological contract: The changing nature of employee-employer expectations', International Journal of Management \& Information Technology 3(1), 62-70 https://doi.org/10.24297/ijmit.v3i1.4642

Banks, J.A. (ed.), 2001, Handbook of research on multicultural education, Jossey Bass, San Francisco, CA. 
Beck, U., 2005, Power in the global age: A new global political economy, Polity Press, Cambridge, UK.

Bhabha, H.K., 1994, The location of culture, Routledge, London.

Biko, S., 1987, 'Our strategy for liberation' in A., Stubbs (ed.) / write what I like, Biko, S. A selection of his writings (Heinemann, Oxford).

Claassens, C. \& Gilfillan, D., 2008, 'The Kalkfontein land purchases: Eighty years on and still struggling for ownership', in A. Claassens \& B. Cousins (eds.), Land, power and custom: Controversies generated by South Africa's Communal Land Rights Act, pp.138-153,UCT Press, Cape Town.

Cousins, B., 2008, 'Characterising "communal" tenure: Nested systems and flexible boundaries', in A. Claassens \& B. Cousins (eds.), Land, power and custom: Controversies generated by South Africa's Communal Land Rights Act, pp. 109-137, UCT Press, Cape Town.

Day, B., 2004, 'From Frankfurt to Ljubljana: Critical theory from Adorno to Žižek', Studies in Social and Political Thought 9(1), 1-20.

Dei, G.J.S., 2018, “"Black like me”: Reframing blackness for decolonial politics', Educational Studies 54(2), 117-142. https://doi.org/10.1080/00131946.2018. 1427586

Delpit, L.D., 1988, 'The silenced dialogue: Power and pedagogy in educating other people's children', Harvard Educational Review 58, 280-298. https://doi.org/ people's children', Harvard Educational
10.17763/haer.58.3.c43481778r528qw4

Derrida, L., 1982, Margins of philosophy, trans. A. Bass, University of Chicago Press, Chicago, IL.

Dewey, J., 1934, 'Dewey outlines utopian schools', in J.A. Boydston (ed.), John Dewey, the later works, volume 9, 1933-1934, pp. 136--140, Southern Illinois University Press, Carbondale, IL.

Du Bois, W.E.B., 1999, The souls of black folk. Authoritative text. Contexts. Criticisms, edited by H.L. Gates Jr. \& T.H. Oliver, W. W. Norton \& Co, New York.

Fanon, F., 2008 [1952], Black skin, white masks, Grove Press, New York.

Freire, P., 2000, Pedagogy of the oppressed, transl. M.B. Ramos, Continuum International Publishing Group, New York. (Original work published in 1970).

Freud, S., 2010, The interpretation of dreams, transl. J. Stratchey, Basic Books, New York.

Gordon, L.R., 2011, 'Shifting the geography in an age of disciplinary decadence. Transmodernity', Journal of Peripheral Cultural Production of the Luso-Hispanic World 1(2), 95-103.

Grosfoguel, R., 2007, 'The epistemic decolonial turn', Cultural Studies 21(2-3), 211-223. https://doi.org/10.1080/09502380601162514

Heleta, S., 2016, 'Decolonisation of higher education: Dismantling epistemic violence and Eurocentrism in South Africa', Transformation in Higher Education 1(1), 1-8. https://doi.org/10.4102/the.v1i1.9

Journet, N., 2009, Evrenselden özele kültür [La Culture: De L'universel au Particulier], iz Yayıncilık, İstanbul.

Kraidy, M.M. 2002, 'Hybridity in cultural globalization', Communication Theory 12(3), 316-339. https://doi.org/10.1093/ct/12.3.316
Maldonado-Torres, N., 2015, 'Forthcoming. "Decolonial Turn"', in J. Poblete (ed.) Twenty-five years of turns in Latin American studies, culture, power and politics, Critical Ethnic Studies, pp. 435-462, Duke University Press.

Mashau, T.D. \& Mangoedi, L., 2015, 'Faith communities, social exclusion, homelessness and disability: Transforming the margins in the city of Tshwane', HTS Teologiese Studies/Theological Studies 71(3), Art. \#3088, 1-9. https://doi.org/10.4102/hts. v71i3.3088

Mazrui, A.A., 1986, The Africans: A triple heritage, BBC Publications, London.

Mbembe, A. 2016, 'Decolonising the university: New directions', Arts \& Humanities in Higher Education 15(1), 29-45. https://doi.org/10.1177/1474022215618513

Mignolo, W.D., 2007, 'Introduction', Cultural Studies 21(2-3), 155-167. https://doi. org/10.1080/09502380601162498

Mignolo, W.D., 2011,1 am where I think: Remapping the order of knowing', in F. Lionnet \& S. Shih (eds.), The creolization of theory, pp. 159-192, Duke University Press, Durham.

Naidoo, M., 2015, 'Transformative remedies towards managing diversity in South African theological education', HTS Teologiese Studies/Theological Studies 71(2) 1-7. https://doi.org/10.4102/hts.v71i2.2667

Ndlovu-Gatsheni, S.J. 2011, 'Colonial Modernity and the African Worldview: Theorizing and historicising religious encounters in South-Western Zimbabwe', Eastern African Social Science Review 27(2), 91-114. https://doi.org/10.1353/eas.2011.0009

Ndlovu-Gatsheni, S.J., 2013, Empire, global coloniality and African subjectivity, Berghahn Books, New York \& Oxford.

Ngugi wa Thiong'o, 2009, Re-Membering Africa, East African Educational Publishers Ltd., Nairobi.

Nyoni, J., 2013, 'Decolonial multicultural education in post-apartheid South Africa', International Journal for Innovation Education and Research 1(3), 83-92.

Ogbu, J.U., 1990, 'Overcoming racial barriers to equal access', in J.I. Goodlad \& P. Keating (eds.), Access to knowledge: An agenda for our nation's schools pp. 59-89, The College Board, New York.

Papastergiadis, N., 2000, The turbulence of migration: Globalization, deterritorialization, and hybridity, Polity Press, Cambridge, UK.

Pieterse, J.N., 2001, 'Hybridity, so what?', Theory, Culture and Society 18(2), 219-245. https://doi.org/10.1177/02632760122051715

Pillay, S., 2015, 'Decolonising the university', Africa is a Country, viewed 16 June 2016, from http://africasacountry.com/2015/06/decolonizing-the-university/.

Quijano, A., 2007, 'Coloniality and modernity/rationality', Cultural Studies 21(2-3), 168-178. https://doi.org/10.1080/09502380601164353

Said, E.W., 1995 [1978], Orientalism: Western Conceptions of the Orient with a new afterword, Penguin, London.

Shade, B.J., (ed.), 1989, Culture, style, and the educative process, Charles C Thomas, Springfield, IL.

Spivak, G.C., 1990, 'The political economy of women as seen by a literary critic', in E. Weed (ed.), Coming to terms: Feminism, theory, politics, pp. 218-229, Routledge, London.

Young, R.C., 1995, Colonial desire: Hybridity in theory, culture and race, Routledge, London. 